\title{
ESPAÑA EN EL PERIÓDICO SLOVENSKI NAROD 1868
}

En mi lengua, el esloveno, e igualmente en el serbio y en el croata, ${ }^{1}$ el término španska vas »pueblo español« sirve para expresar algo desconocido o poco conocido, lejano, fuera de la conciencia de quien habla.

No por eso, como querría sugerir dicha expresión, hay que creer que en los tiempos pasados España y diferentes aspectos de ella fuesen totalmente desconocidos en el área eslovena, por lo menos no en el ambiente cultural. En la literatura eslovena, desde el siglo XIX, hay bastantes referencias en cuanto a la cultura, historia o geografía de España. Lo demuestran los poetas, como el más elevado genio de la época romántica Francè Prešeren (1800-1849, véase sobre el poeta Verba Hispanica IV) en cuya obra poética se encuentran trozos que demuestran por lo menos conocimientos culturales, como muestra el ejemplo en el soneto Marskteri romar gre v Rim, v Kompostelje, "Más de un peregrino va a Roma, a (Santiago de) Compostela"; o cuando en Glosa se refiere a la triste suerte de los poetas, incluidos la de los creadores de Lusíadas o del Quijote. Además, hay reminiscencias de la vieja creación poética española, como en el soneto $\mathrm{Ni}$ znal molitve žlahtnič trde glave, "no sabía otra oración el joven noble", motivo que refleja el de un milagro de la Virgen en Alfonso el Sabio y en Berceo. Sin pasar por alto tampoco la tradición popular: en un cuento lírico, Lepa Vida, símbolo de anhelo no apagado, aparecen la corte y la Reina de España.

Estas páginas no quieren otra cosa que copiar fielmente de un viejo periódico esloveno informaciones ofrecidas a los lectores sobre los acontecimientos de aquel tiempo en España. Tienen su valor por la fecha venerable, la publicación del año que examinamos es de la segunda mitad del siglo XIX, y por el hecho de haber estado publicado el periódico en una pequeña ciudad a orillas del río Drava, Maribor, que a la sazón contaba con nada más que unos cinco mil habitantes y en aquella época pertenecía al ducado de Estiria Meridional del Imperio Austro-Húngaro, y escrito en una lengua eslava, por aquel entonces por cierto totalmente desconocida para los españoles. Slovenski narod, "Pueblo esloveno" (1868-1943), de tendencias liberales en política, decididamente anticlerical, aparecía en los primeros años de su vida sólo tres veces por semana, más tarde, trasladada la redacción en 1872 a Ljubljana, llegó a ser el más importante diario de orientación liberal; por su profesionalidad, según la opinión de muchos, gozó siempre de alta consideración.

Y, por casualidad, el primer año de su aparición, 1868, coincide con hechos importantes de la historia española. Sea lo que fuere, por lo menos en los meses de septiembre

\footnotetext{
"Véase Karlo Budor, Serbocroata "španska sela" (pueblos españoles) - apuntes marginales sobre la ignorancia, Studia romanica et anglica zagrabensia, 37, Zagreb 1974, pp. 287-293. - El autor opina para el serbocroata (Budor escribe en 1974), "como la expresión no se basa en ninguna relación directa humana o histórica entre las dos naciones", p. 288, a un calco de la análoga expresión idiomática alemana spanische Dörfer.
} 
y octubre, de los acontecimientos de ningún otro Estado fuera de la monarquía austro-húngara se dan más noticias que del Reino de España. Vamos a transcribirlas, todas, en el original esloveno, seguidas de la respectiva traducción española ${ }^{2}$, para ver hasta qué punto y de qué manera el lector esloveno pudo estar informado, teniendo siempre presente las tendencias políticas del periódico. Hay que destacar, quizás, en las noticias dos motivos: uno es el anticlericalismo - no en vano el Slovenski narod es pregonero de las ideas políticas liberales - y el otro es una evidente hostilidad hacia el régimen monárquico y por esto una clara inclinación hacia el sistema republicano en España. Hay que tener en cuenta, además, que el periodista en pleno régimen habsbúrguico, sí, relata los acontecimientos del extranjero, pero descubre en el mismo tiempo las ideas pro domo sua.

\section{8 de abril}

Predsednik španskega ministerstva, maršal Narvaez je umrl. Njegov naslednik je Bravo, ki je že razglasil, da hoče gospodariti po izgledu svojega prednika. Posebnega veselja menda s tem Španjski ni napravil. Ali bi se morebiti imel kdo veseliti, ko Bravo obeta, da hoče zvest ostati politiki verolomstva, nasilstva in brezumnega natražništva.

El presidente del Consejo, el mariscal Narváez ha muerto. Su sucesor es Bravo que ya declaró querer gobernar siguiendo el ejemplo de su predecesor. A España con esto no le causó una gran alegría. ¿O es que alguien tenía que haberse alegrado, cuando Bravo asegura que quiere continuar fielmente una política de felonía, violencia e irrazonable reacción?

\section{2 de mayo}

Na Španjskem se zopet pogosto imenuje general Prim, znan po večih puntih, posebno zadnjih let. Za zdaj se ne vé za Primovo bivališče. Nekteri imenujejo London, drugi Bruselj. Njegov sel išče zdaj v Parizu denarja.

En España se menciona frecuentemente al general Prim, conocido por sus muchas rebeliones, especialmente durante los últimos años. Por ahora se desconoce su paradero. Algunos dicen que se encuentra en Londres; otros, en Bruselas. En París su emisario está buscando dinero.

\section{2 de julio}

Zasebna pisma iz Madrida pripovedujejo, da je tudi tam z Barbonskim vladarjem že na pol pri koncu. Brez dvombe ima demokratična mnogo privržencev in prijateljev in celo $v$ kasarnah se razlega glas: V kraj z Burboni, dajte nam vsem pravico do glasovanja.

Cartas particulares de Madrid cuentan que también allí el reinado de la dinastía borbónica está tocando a su fin. Sin duda el partido demócrata cuenta con muchos partidarios y simpatizantes; incluso en los cuarteles se oye la voz: " Afuera los Borbones, dadnos a todos el derecho de votar!"

${ }^{2}$ La versión española ha sido revisada por Iván Reymóndez, lector de lengua española de la Facultad de Letras de Ljubljana. 
11 de julio

Na Španjskem se snuje nova revolucija; zapletenih je v punt več generalov, kterih so že nekoliko priprli.

En España se está gestando-otra rebelión; en el motín están implicados muchos generales, de los cuales algunos ya han sido encarcelados.

\section{6 de Julio}

Zdaj ko so veliki politikarji veči del po toplicah in toraj vse, politika takorekoč miruje, mora španski punt nadomeščati, kar drugod manjka. Vjete generale so odposlali na Kanarske otoke, kraljičina sestra in njen mož Montpensier sta morala deželo zapustiti in sta šla v Anglijo. Tudi na Portugalskem je neki vse v neredu. Gotovega se vendar nič ne izvé, ker brzojav sporoča, kar je vladi po volji. Kraljica je zaukazala, da imajo vojne ladje špansko obrě̌je čuvati; ne vé se še, ali za to, da bi uporniki ne ubežali, ali da bi ne dobivali zunanje pomoči.

Po privatnih pismih poslanih v Pariz, so se združile pri puntu vse različne napredovalne stranke, da bi odpravile dosedanjo samovoljno vlado. Vporu je na čelu stal g. Espartero, ktermu sta se bila pridružila tudi g. Prim in Olozaga. Punt bi se bil imel dvigniti v Kataloniji, v gorenji Aragoniji pa šele konec tega meseca. Če je tudi vlada dozdaj že 350 viših in nižih častnikov in tudi nekoliko civilistov polovila, vendar ni gotovo ali bo mogla punt vdušiti. Zdaj je poslala nekoliko polkov v Katalonijo.

Špansko poslanstvo trdi, da je ves punt že uničen in da se vladi ni ničesar več bati. Sploh je videti, kakor da bi imeli pariški službeni listi povelje vse špansko gibanje zamolčati.

Ahora, en pleno verano, cuando casi todos los grandes políticos están de vacaciones en centros termales y la actividad política se encuentra, por ende, parada; para el periodismo la rebelión española reemplaza lo que falta. Los generales capturados han sido enviados a las Islas Canarias, la hermana de la Reina y su marido Montpensier han tenido que abandonar el país y se han trasladado a Inglaterra. Según parece, hay desórdenes también en Portugal. Tener noticias seguras es imposible: el telégrafo notifica lo que agrada al Gobierno. La Reina ha mandado que las naves militares guarden el litoral español; no se sabe todavía si por qué los rebeldes no huyan o por qué no puedan recibir ayudas del extranjero.

Según cartas particulares enviadas a París, se han juntado en el motín todos los partidos progresistas con el intento de acabar con el obstinado gobierno actual. A la cabeza de la rebelión se encontraba Espartero, al cual se asociaron también los señores Prim y Olózaga. El motín tendría que iniciar en Cataluña; en el Alto Aragón sólo a finales del mes corriente. Aunque el Gobierno ha hecho detener hasta la fecha a 350 oficiales, superiores e inferiores, y también a muchos civiles, no es seguro que pueda sofocar el motín. Actualmente ha enviado algunos regimientos a Cataluña.

La Embajada de España sostiene que el motín ya ha sido sofocado en su integridad y que el Gobierno no tiene nada que temer. En general, parece como si la prensa oficial parisina tuviese la orden de guardar silencio en torno al levantamiento español. 
21 de julio

Brzojav naznanja, da so v Porto Maurizio zaprli dva Španjca, ki sta za španjski punt vojake nabirala. Španjska vlada je neki italijanski ovadila, da je med španskimi uporniki in italijanskimi republikanci neka zveza, in da bi bil pri šp. uporu tudi Mazzini toliko vdeležen, da je nekoliko 1000 italijanskih prostovoljcev obljubil proti temu, da bi v potrebi tudi Španjci enako pomagali.

Sicer pa iz Španskega ni nič zanesljivega zvedeti, kar današnji dan pové, oporeče drugi. Pisma od 15. t.m. poročajo, da se vojvoda Montpensier ni hotel vdati vladinemu zaukazu, čě da sme španskim infantom le monarh sam zaukazovati. Razen njega so vsi generali, ki so bili pri liberalni stranki, iz dežele izgnani.

El telégrafo anuncia que en Porto Maurizio (hoy, Imperia en la costa ligura en el Golfo de Génova, N.T.) han arrestado a dos españoles que se dedicaban a reclutar soldados para la sublevación española. El Gobierno español habría hecho saber al italiano que existe una conexión entre los amotinados españoles y los republicanos italianos y que en la rebelión española está implicado en cierta manera también Mazzini, el cual habría prometido algunos miles de voluntarios italianos a cambio de que, en caso de necesidad, los españoles les ayudasen de la misma manera.

Por otra parte, de España no es posible obtener noticias seguras: lo que se informa el día de hoy, se niega al día siguiente.

Las cartas del quince del mes corriente informan que el Duque de Montpensier se ha negado a respetar la orden del Gobierno, ya que a un infante español no le puede dar órdenes nadie más que el monarca mismo. Excepto él, han sido expulsados del país todos los generales que eran miembros del partido liberal.

23 de julio

Na Španjskem ne morejo ministrov dobiti, ker se noče nihče ministrovanja lotiti proti javnemu mnenju in ljudskim željam.

Dvorni časniki v Madridu so začeli pisati o španskem uporu, znamenje, da je videti, kakor da bi bil upor potlačen. Po tem pisanju je videti, da vlada ni vdušila že začetega punta, ampak da se je še le zanj pripravljalo. "Daily Telegraf" pripoveduje zanimivo črtico iz življenja sedanjega ministra Gonzales Bravo.

Ko je bil namreč še navaden državljan in tudi ni imel nobenega upanja, da bi kedaj postal minister, ponudil se je bil zdaj iz dežele iztiranemu vojvodi Montpensieru, da bi zanj napravil punt in zaroto proti kraljici. Vojvoda ponudbe ni sprejel, zdaj ga je pa isti ponujalec iz dežele izgnal.

En España no pueden encontrar ministros, porque nadie quiere cargar sobre sí una tarea ingrata, contraria a la opinión pública y a los deseos del pueblo.

Los periódicos de la corte madrileña han empezado a escribir sobre la rebelión española, señal de querer ver el motín como ya sofocado. La situación se presenta como si el Gobierno no hubiese sofocado sino los preparativos de la rebelión. Del currículum del actual ministro, González Bravo, "Daily Telegraf" cuenta un interesante detalle. 
Cuando éste era un simple ciudadano y no tenía ninguna esperanza de llegar a ser ministro, se le ofreció al actualmente exiliado Duque de Montpensier para preparar en su favor un motín y conspiración contra la Reina. El duque rechazó la proposición y ahora el mismo oferente lo ha hecho desterrar.

\section{5 de julio}

Francoska strogo straži španjsko granico, da ne bi mogel Prim v deželo. Gotovo je, da je francoska policija tirjala, naj se Montpensier iz dežele izžene.

Iz Madrida se zagotavlja, da je po sporočilu španskega poslanca $v$ Angliji general Prim zapustil London in se napotil $v$ Lisabon. Zatorej pričakujejo, da se bo razglasil posadni stan. Prijatlji ministrstva so v velikem strahu.

Francia vigila rigurosamente la frontera para impedir a Prim entrar en el Estado. Es cierto que fue la policía francesa la que exigió la expulsión de Montpensier.

Desde Madrid se afirma que según el despacho del embajador de España en Inglaterra, el general Prim ya ha salido de Londres con destino a Lisboa. Por eso se aguarda el anuncio de estado de sitio. Los amigos del ministerio se muestran terriblemente espantados.

6 de agosto

Na Španjskem se je novih uporov bati; posebno se ni zanašati na mornarske častnike.

En España hay que temer nuevas rebeliones; no hay que fiarse, sobretodo, de los oficiales de marina.

\section{8 de agosto}

Iz Španjske se sliši, da so uporne čete v Aragoniji dale vojakom opraviti, tudi v provinci Kadiks se kaže resno uporstvo, kterga je moralo tudi vojaštvo "tolažiti".

De España se oye que las tropas rebeldes en Aragón han dado mucho que hacer al ejército: también en la provincia de Cádiz se verifica una sublevación que el ejército tuvo que "mitigar".

\section{3 de agosto}

Španjska vlada ne pusti nobenega sporočila čez mejo, kteri jej ni po godi. Časnikom in ljudem so usta zamašena, nihče si ne upa govoriti, če noče v ječo ali pa iz dežele. Imenitnih mož čez noč iz njihovih stanovanj zmanjka in nihče več jih ne vidi; ne ve se, kaj se je zgodilo z generali, ktere so bili na balearske otoke odpeljali.

El Gobierno español no deja pasar la frontera a ningún informe que no sea en su favor. A los periódicos y a la gente les han tapado la boca, nadie se atreve a hablar por miedo de ser encarcelado o exiliado. Hay casos de personalidades destacadas que de noche desaparecen de su propia casa y a nadie los vuelve a ver; se desconoce lo que ha ocurrido a los generales que fueron enviados a las Islas Baleares. 
Španjski minister notranjih zadev je poslal po deželi okrožnico, v kteri svoje namestnike opominja, naj bi svoje podpore posebno pri deželnih brambovcih in narodni straži iskali, kajti na redno vojsko se ni zanašati. Vznemirujočih glasov ni konec, vlada pripravlja, kar je mogoče, da bi se varovala; ali to vso deželo zelo tlači in posebno na borzi je vse pobito. Banka posojuje vladi svoje novce za le oderuške obresti.

El ministro de Asuntos Interiores ha repartido una circular en la que advierte a sus subalternos de la búsqueda de apoyo sobretodo entre los milicianos y la Guardia Civil porque con el ejército regular no hay que contar. No se calman los rumores de que el Gobierno está haciendo todo lo posible para sostenerse; todo esto oprime la vida del país y sobre todo en la Bolsa impera una depresión total. La banca concede al Gobierno préstamos pero sólo a interés de usurario.

\section{2 de agosto}

Na Španjskem so vsled zadnjega upora mnogo častnikov kaznovali; na to se je več častnikov službi odpovedalo in tudi vojni minister je odstopil.

En España, a causa de la última sublevación, muchos oficiales han sido castigados; acto seguido, muchos oficiales han renunciado a su cargo; ha dimitido también el ministro de Guerra.

\section{7 de agosto}

Pariz 24. avg. "France” pripoveduje, da se je v šanjskem ministerstvu nekoliko sprememb nadejati, kedar se vrne kraljica domu.

Despacho de París, día 24: "France" cuenta que hay que esperar algunos cambios en el ministerio español, en cuanto se produzca el regreso de la Reina.

29 de agosto

Na Španjskem vré kakor povsod: pišejo, da je treba samo drznega moža, ki bi se nezadovoljnežem za vodnika na čelo postavil in upor zoper kraljico, ki neče narodove želje poslušati, bi bil gotov. Kraljica se menda sama že boji, ker je vse svoje dragocenosti dala iz Madrida $v$ Lequeitio prenesti. Kakor pred leti $v$ Neapolji, kliče se tudi zdaj $v$ Španiji sploh: "Proč z burbonsko vladno družino".

En España hierve por todas partes: escriben que no se necesita más que un hombre audaz que asuma la responsabilidad de guiar a los descontentos para que la sublevación contra la Reina, que no quiere escuchar los deseos del pueblo, sea un hecho. La Reina, según parece, tiene miedo: ha hecho trasladar todas sus joyas desde Madrid a Lequeitio. Como ocurrió hace años en Nápoles, hoy en España se oyen gritos como "iFuera la familia real borbona!" 


\section{1 de septiembre}

Španjski listi so sploh proti vsaki zvezi s Francijo in hočejo le s Prusijo in Italijo v prijateljstvo stopiti. Francija je še vselej Španijo škodovala in le za se skrbela.

La prensa española es en general contraria a cualquier relación con Francia y prefiere lazos de amistad sólo con Prusia e Italia. Francia siempre ha ocasionado perjuicios y se ha preocupado exclusivamente de sus intereses propios.

3 de septiembre

Na Španjskem so našli skrivnih zalog za orožje in strelivo. Na toledskih gorah so se prikazale oborožene sile!

En España han sido descubiertos depósitos clandestinos de armas y municiones. ¡En los Montes de Toledo han aparecido tropas armadas!

\section{5 de septiembre}

Ko bi se primerila vojska med Prusijo in Francijo, je obljubila Španjska 30.000 vojakov za posado $v$ Rim. Španjski pač ni za nekoliko vojakov, vesela je če nezadovoljneže iz dežele spravi.

En caso de guerra entre Prusia y Francia, España ha prometido poner 30.000 soldados a disposición de la guarnición de Roma. Por lo visto no le interesan a España algunos soldados, estará contenta de poder desalojar del país a los descontentos.

\section{2 de septiembre}

Na Španjskem se je zopet punta bati, pričeti se ima neki v provinciji Galicija. Vladi so neki nameni vsi znani, vendar nima moči gibanje za zdaj vdušiti.

Iz Pariza se piše v "Times". Kraljica počasi spoznava svoje nevarno stanje in se je jela pripravljati za hude čase. Veliko gotovine je že v London poslala, prodaja posestva in si išče starih tirjatev do dežele, ktere bo potem $v$ denar spravila.

En España hay que temer otra vez una rebelión que empezaría en la provincia de Galicia. El Gobierno es conocedor de tales intenciones, pero no tiene fuerza para sofocar el movimiento.

Con despacho de París se publica en "Times" que la Reina de España se da poco a poco cuenta de lo peligroso de su situación y que ha empezado a prepararse para los malos tiempos. Ha hecho transferir a Londres mucha moneda contante, está vendiendo sus posesiones y hace viejas reclamaciones de pago, deudas del Estado que, después, podría transformar en dinero líquido.

\section{4 de septiembre}

Španjski punt je le na videz vdušen, pod pepelom je ogenj najprej tlel, kar je celo naravno, ker se ni najmenjša trohica v negnjusno samovoljnem in slabem gospodarstvu in vladanji zboljšala. Vnel se je zdaj tem živahnije. Vse stranke so se združile, da odpra- 
vijo nepriljubljeno, nesposobno kraljico z njenim vojaškim repom priliznjencev. Iz dežele izgnani generali so se vrnili, Prim in Aoda sta na potu proti Madridu. Vse državno brodovje je odpadlo ter se pridružilo upornikom. Brati je, da se je kraljica odpovedala sinu na korist. Punt ima federalistično-republikanski namen.

Najnovejše vesti.

Pariz. Grof Girgenti je potoval v Madrid, več voditeljev radikalne stranke španjske je še tu. Vojni minister misli pustiti 80.000 gl. na dom. ${ }^{3}$ Mesto Kadiks so dobili uporniki $v$ roke.

La rebelión en España se sofocó sólo en apariencia; el fuego continuaba ardiendo bajo la ceniza, lo que es natural ya que no se produjo la más mínima mejora en la repugnante autocracia ni en la mala economía. El fuego se reavivó con mayor brío. Se pusieron de acuerdo todos los partidos para destronar a la impopular e incapaz Reina con toda su recua militar de aduladores. Han regresado los generales desterrados del país. Prim y Aoda están a punto de llegar a Madrid. Toda la marina militar ha desertado, uniéndose a los rebeldes. Léese también que la Reina ha abdicado a favor de su hijo. La rebelión tiene tintes federal-republicanos.

Últimas noticias.

París. El conde de Girgenti se ha marchado a Madrid, mientras otros jefes del Partido Radical Español se encuentran todavía aquí. El ministro de Guerra /francés/ tiene intención de dejar 80.000 soldados en casa. ${ }^{3}$ Los rebeldes han tomado la ciudad de Cádiz.

\section{6 de septiembre}

Dasiravno ne moremo vsem sporočilom o španjskem uporu na besedo verjeti, to je vendar gotovo, da je upor skoraj splošen in krepkeji, kakor smo jih v Španiji vajeni. Da je marina prestopila $k$ upornikom, je neizmerljive važnosti. Vse obrežje je v rokah upornikov, in od todi gre upor dalje proti sredini, razen tega se ne se prezirati moralični upljiv kterega ima ta prestop na ljudstvo. Marina se dozdaj še ni nikdar pri uporih udeleževala in uživa med ljudstvom mnogo spoštovanja. Program zedinjenih upornikov je za zdaj: 1. burbonski dinastiji se za viselej vzame vladarstvo; 2. mesto nje nastopi začasna vlada; 3. sklicati se ima ustavodejni zbor, ki bo polnovlastno odločeval o prihodnji osodi španskega kraljestva. Vojvoda Montpensier in infantinja Maria Luiza sta neki tudi uporu pristopila.

Aunque no podemos dar crédito a todos los informes sobre la insurrección española, es cierto que ésta es casi general y más vigorosa de lo que estábamos acostumbrados a constatar en España. Que la Marina se ha pasado al bando de los rebeldes supone un hecho de importancia inconmensurable. Todas las costas mediterráneas están en manos de los rebeldes y desde aquí la sedición se extiende hacia el interior. $\mathrm{Y}$, además, no hay

3 En el original esloveno la noticia fue estropeada: se refiere a una decisión del ministro de guerra francés: lo comprobó, detrás de mi hesitación en comprenderla, el historiador esloveno prof. Vasilij Melik, comparando las noticias publicadas en Laibacher Zeitung, el diario alemán de Ljubljana, de aquellos mismos días. 
que despreciar la influencia moral que esta adhesión tiene entre el pueblo. Hasta ahora, la Marina no había participado nunca en los amotinamientos y goza entre la población de un alto grado de respetabilidad. El programa de los rebeldes reunidos es, por el momento, el siguiente:

1. se priva para siempre a la dinastía borbónica de la posibilidad de reinar;

2. le sucede un Gobierno Provisional;

3. hay que convocar Cortes Constituyentes que decidan con plenos poderes sobre la futura suerte del Reino de España.

El duque de Montpensier y la infanta doña María Luisa se han unido, según parece, a la sublevación.

\section{9 de septiembre}

Revolucija (upor) na Španjskem je zdaj najimenitnejša reč, kar se iz tujih dežel novosti poročuje. Upornikov je čedalje več in pomorska vojska jemlje po obrežji mesto za mestom vladni oblasti. Kraljica, ktero zaradi njenega nenajčistejega življenja in zaradi strašnega zatiranja vsacega svobodnega gibanja ljudstvo sovraži, ne more v glavno mesto Madrid, ker so jej uporniki pot zaprli. Pravijo, da upornikom pomaga Prusija $z$ denarjem in da orožje dobivajo iz Amerike.

La revolución en España resulta actualmente la cosa más destacada de todas las que se relatan desde países extranjeros. Aumenta el número de los rebeldes y, en la costa, la Marina arrebata al Gobierno el control de las ciudades, una por una. La Reina no puede regresar a la capital, Madrid, ya que los rebeldes le han cortado el acceso; el pueblo la detesta por su no irreprochable vida y por la terrible represión de todo movimiento liberador. Se dice que Prusia ayuda a los rebeldes con dinero y que reciben armas de América.

\section{1 de octubre}

Francoska vlada je sporočila $v$ Španijo, da se ona (Fr.) nikakor ne bo vtikala $v$ španjske zadeve, da pa sicer ničesar ne želi nego miru.

$O$ španjskem uporu se piše mnogo. Kraljica ima malo prijateljev in še ti so nezanesljivi. Ljudstvo je kakor se vidi skoraj povsod zoper njo in njeno rodovino. Edino na vojaštvo se zanaša. Da pa to ni velika zaslomba za njen prestol, kaže to, da generali $z$ vsemi regimenti stopajo na stran upornikov, kakor se poroča o Girgentiju. Vsim upornikom je glasilo: Proč s kraljevo rodovino, občna volilna pravica, ustavodajni zbor po ljudstvu izbranih poverjenikih (Kortes). Tudi po mestih kjer se revolucija še ni vzdignila, razglašajo se od začasne skrivne vlade uporni oklici, ki se po ena mesta javno delé, kar kaže, da je vlada že čisto slaba in nezmožna braniti se. Iz mest, kjer je revolucija določno vzdignila glavo, beže vladni ljudje. Vodniki upornikov so generali Prim, Dulce, Bedoya, Topete in drugi. Posamezna poročila se še ne dade dobro razbrati, čakati nam je, da se potrdijo.

Iz Florence. Po ljudski govorici pišejo nekteri časniki, da se hoče Garibaldijev sin Menotti napraviti $v$ Španijo na pot. 
Iz Pariza. Dve španjski ladiji ste prišle pred Lisabono, da bi vojvodo Montpensiera povabile, naj se odpelje v uporne okraje.

Iz Rima. Antonelli je neki naročil španjskim škofom, naj z vso svojo oblastjo skušajo upor zadušiti. Sv. oče so neki v posebnem pismu kraljico Izabelo obžalovali.

El gobierno francés ha notificado a España que Francia no quiere entrometerse en absoluto en los acontecimientos españoles; lo único que desea es la paz.

Se escribe mucho sobre la insurrección española. La Reina tiene pocos amigos y aun estos no de mucha confianza. Ya se ve que el pueblo es contrario a ella y a su familia real. Cuenta sólo con el ejército; que eso no es un verdadero sostén para su trono, lo demuestra el hecho de que los generales con todos sus regimientos se hayan puesto de parte de los rebeldes; tal como se notifica de Girgenti. Es consigna de todos los rebeldes: ¡Fuera con la dinastía real!, Derecho de Sufragio Universal, Cortes Constituyentes elegidas por los delegados, elegidos a su vez por el pueblo. Incluso en las ciudades donde todavía no hay movimiento revolucionario, el Gobierno clandestino está distribuyendo públicamente manifiestos para llamar a la sedición, sin que el Gobierno intervenga, lo que prueba su debilidad e incapacidad para defenderse. Al contrario, de las ciudades donde la revolución ya se ha hecho con el poder huyen los adeptos del Gobierno. Los jefes de los rebeldes son los generales Prim, Dulce, Bedoya, Topete y otros. Dichos hechos no se han podido leer todavía; hay que esperar a que sean confirmados.

Desde Florencia. De acuerdo con los rumores que circulan entre el pueblo escriben unos periódicos que el hijo de Garibaldi, Menotti, quiere ponerse en camino hacia España.

Desde Roma. Antonelli (cardenal-ministro de Estado del papa Pio IX, N.T.) habría encargado a los obispos españoles intentar sofocar la sublevación con toda su autoridad. El Santo Padre en su carta particular se habría compadecido de la Reina Isabel.

\section{3 de octubre}

Španjski punt se je za upornike po sreči izšel. Glavno mesto se je brez ustavljanja udalo upornikom. Kraljica je Španijo popustila in je šla na Francosko. General Novaliches je v boji $z$ uporniki ranjen padel. Njegova vojska je večidel $k$ upornikom prestopila. Ljudstvo je oboroženo. Novi uradniki so postavljeni.

La insurrección española ha tenido un fin favorable para los rebeldes. La capital se entregó sin resistencia. La Reina salió de España retirándose a Francia. El general Novaliches, herido, cayó durante las hostilidades. La mayoría de sus tropas se pasó al bando de los rebeldes. La gente está armada. Se ha producido el relevo de muchos funcionarios públicos.

6 de octubre

$V$ Rimu so se zmage španske revolucije zelo prestrašili. Papeževe vlade poslanec je poklican iz Madrida.

Pregnana španjska kraljica je iz Francoskega poslala protest. Kakor kaže se Španjci zanj ne bodo zmenili. Oboroženo ljudstvo je z vojaki, ki so skoraj vsi k revolucijonar- 
jem prestopili edino. Kakošno vlado bodo Španjci dobili še ni določeno. Največ glasov se čuje za zedinjenje iberskega polotoka, t.j. Španije s Portugalsko. Volitve, ki se naglo vrše, še niso povsod dokončane.

En Roma la victoria de la revolución ha provocado espanto. El embajador de la Santa Sede ha sido llamado a Roma.

La Reina exiliada ha enviado desde Francia una protesta. Parece que los españoles no se van a preocupar más por la protesta. El pueblo armado está unido a los soldados que casi en su totalidad se han unido a los revolucionarios. Todavía no está claro qué tipo de gobierno tendrá España. La mayoría de las voces abogan por una unión de la Península Ibérica, es decir, de España con Portugal. Las elecciones, aunque en pleno desarrollo, todavía no han concluido en todas las comarcas.

\section{8 de octubre}

Španjska revolucija je za zdaj končana. Najnovejši telegrami pripovedujejo, da se bo ustanovilo ministerstvo, ki bo imelo vlado $v$ rokah, dokler se ne snide ustavodejni zbor. Ali bo postala potem Španjska republika ali ustavna monarhija, to se še le vgiblje, jasno menda celo voditeljem španske revolucije ni. Nekteri hočejo trditi, da španjsko ljudstvo za to še ni zrelo. Španjska kraljica je iz Francije poslala razglas v Španijo, ki se pa še ne zmeni za svojo prejšnjo "osrečevalko".

Anglijski poročnik v Španiji je dobil povelje novemu vladarstvu naznaniti, da se Anglija nikakor ne bo vtikala $v$ to, kako si bo osvobodeno španjsko ljudstvo svojo bodočnost snovalo, ako bi ne zašlo na pota, ktera bi vtegnila tudi zunajne razmere španjske spreminjati. Enako misli tudi Francija poročati v Madrid.

Por ahora la revolución española parece concluida. Los últimos telegramas dicen que se formará un ministerio para gobernar hasta que se reúnan las Cortes Constituyentes. Que España se vaya a convertir en una república o en una monarquía constitucional es objeto de conjeturas; esto no parece claro tampoco para los jefes de la revolución. Hay voces según las cuales la nación española no es todavía madura para ello. La Reina ha enviado a España desde Francia un manifiesto, pero España no se preocupa ya de su anterior "bienhechora".

El representante inglés en España ha recibido el mandato de hacer saber a las nuevas autoridades que Inglaterra no quiere en modo alguno entrometerse en las soluciones que el pueblo español emancipado tome para construir su futuro, a condición de que esto no suponga alteración o perjuicio en las relaciones externas. Francia quiere adoptar idéntica postura.

\section{0 de octubre}

Protest, kterega je poslala izgnana španska kraljica v svoje nekdanje kraljestvo, nikakor ne moti mirnega razvoja. Začasna vlada bo ali je že protest dala $v$ tisk in ga bo povsod javno nabila. Pristavila mu je uvod: kraljica je namenila španskemu ljudstvu nek protest. Začasna vlada noče o tem nikakor soditi, španjsko ljudstvo, ki je samovlastno sodilo kraljičino delo, sodilo bo tudi njene besede. Ves punt je dozdaj popolnoma složen 
in oni, ki so meščanske vojske prerokovali, varali so se do živega. Zdaj so tudi oni generali, ki so se borili proti liberalni armadi, pripoznali revolucijo. Gen. Prim je prišel v Madrid kjer je bil slovesno sprejet. Na Portugalskem niso čutili nikakoršnjega vpliva vsled španjske revolucije.

El manifiesto, enviado por la Reina desterrada a su ex-reino, de ninguna manera perturba el desarrollo pacífico de los hechos. El Gobierno Provisional ha hecho imprimir el manifiesto, o lo hará en seguida, para fijarlo públicamente por todas partes. Ha añadido al manifiesto una breve nota: La Reina ha dirigido a la nación española cierta protesta. El Gobierno Provisional no quiere pronunciarse sobre esto, la nación española, que autónomamente ha juzgado el obrar de la Reina, sabrá juzgar también sus palabras. Hasta ahora, toda la sublevación está unida; los que anunciaron una guerra civil se equivocaron por completo. También los generales que lucharon contra el ejército liberal han reconocido la Revolución. El general Prim ha llegado a Madrid, donde ha sido acogido con solemnidad. En Portugal no se ha sentido ningún influjo de la revolución en España.

\section{3 de octubre}

Zapoveljnik španjske armade je zastopnikom tujih vlad naznanil, da je pripravljen in kos popolnoma braniti njihove osebe, naj že stopijo njihove vlade $v$ reden dogovor $s$ sedanjo vlado ali ne. Ob enem je izrekel, da armada ni za to, da bi se napravila iz Španije republika.

Uradna "Goreta" razglaša, da se bo brž ko brž vpeljalo splošno volilno pravo, svobodna vera in uk, pravica do društev in zborov, tiskovna svoboda, decentralizacija uprave, porotnice in popolna neodvisnost sodnikov.

El comandante del ejército español ha anunciado a los representantes de los gobiernos extranjeros que está preparado y es capaz de protegerlos, que los respectivos gobiernos establezcan relaciones normales con el Gobierno actual o no. Asimismo ha declarado que el ejército no es partidario de la idea republicana para España.

La "Gaceta" oficial anuncia que se introducirá cuanto antes el sufragio universal, la libertad de culto y de enseñanza, el derecho de asociación y de reunión pública, la libertad de prensa, la descentralización de la administración y de los tribunales de jurados, la absoluta independencia del juez.

\section{5 de octubre}

Političnemu prestroju v Španiji se pridružuje tudi religijozni. V Madridu so bile demonstracije zoper konkordat. Vlade (junte) nekterih mest so segle po kloštrih, izpodile so menihe in nune. Tudi jezuite baje pode! Iz Barcelone in Cordove so bežali jezuitje v Giberaltar. - Minister notranjih zadev spominja ljudstvo da naj ohrani mir in red, ker je zdanja vlada državne vajeti v roke vzela, da bi narod do svobode pripeljala, ne pa z neredom pogubila. - Vlada Severne Amerike je španjsko revolucijo pripoznala. Povsod v Španiji je mirno. 
Al cambio político le acompaña también el religioso. Se han registrado en Madrid manifestaciones contra el Concordato. Las juntas de algunas ciudades han extendido la mano para tomar posesión de los monasterios, han expulsado a los monjes y a las monjas. ¡Parece que están expulsando también a los Jesuitas!

Desde Barcelona y Córdoba los Jesuitas han huido también a Gibraltar.

El Ministerio de Asuntos Interiores exhorta al pueblo a conservar la calma y el orden público: el gobierno actual ha tomado las riendas del Estado para conducir al pueblo hasta la libertad y no para arruinarlo con el desorden. El Gobierno de los Estados Unidos de América del Norte ha reconocido la revolución española. En todas las partes de España reina la calma.

\section{7 de octubre}

Kako državno obliko bode imela Španija zdaj ko je kraljica spodena ne more se še določiti iz raznih poročil, ktere iz Španije vsi časopisi prinašajo. Veliko upanje je, da bi se kraljestvo spremenilo v federativno republiko, kteri bi na čelu stal Prim, Serano in Olozaga. 15. oktobra so stopili kortes (izbrani narodni poslanci) skupaj: ti imajo določiti prihodno osodo Španije. - Italiji in Prusiji je prekucija in preuredba v Španiji, kakor se iz vsega vidi, prav po godi prišla; ravno narobe pa francoskemu Napoleonu, ki je mislil Italijo in Španijo podse dobiti v "zvezo latinskih narodov", kar se je zdaj ravno narobe obrnilo, tako da bode imel francoski cesar ne samo v Prusiji sovražnika temuč tudi v Italiji in $v$ Španiji.

En base a las diversas informaciones referidas por toda la prensa no es todavía posible pronosticar qué forma de gobierno habrá en España, una vez destronada la Reina. Hay esperanza de que el reino pueda transformarse en república federal, con Prim, Serrano y Olózaga al frente. El 15 de octubre se reunieron las Cortes que tienen que decidir cuál será el futuro de España. Italia y Prusia, como se puede deducir, han recibido de muy buen grado la revolución y el cambio en España; lo contrario Napoleón que tenía la idea de dominar Italia y España con una "unión de naciones latinas", lo que ahora, con este cambio político resulta haberse dado la vuelta: el emperador francés encontrará un enemigo no sólo en Prusia, sino también en Italia y España.

\section{0 de octubre}

Začasna vlada na Španjskem si zdaj kolikor mogoče svoje stanje vreduje. Vodniki upora hodijo od mesta do mesta in si puščajo hvalo peti, ob enem si prizadevajo, da ne bi se navdušenje za nje pomirilo. Vlada si je na Anglijskem 700 milj. izposodila. Tudi v drugih zadevah vlada skrbno dela. Kako zelo načela svobode spoštuje, kaže da je zaukazala, da se ima ostro soditi, ko bi se hišna pravica svojelastno motila; za tiskovne pregrehe je razglašena splošna amnestija, kolonije bodo imele v postavodejnem zboru svoje zastopnike, otroci, ktere bi sužnja rodila, postanejo svobodni. Tudi poročniki v Carigradu, Parizu, Londonu, Dunaji in Berolinu se bodo odpozvali in z drugimi osebami nadomestili.

Za španjski prestol se bota neki poganjala kralj portugalski in vojvoda Montpensier. 
En España el Gobierno Provisional procura estabilizar su posición lo máximo posible. Los jefes de la insurrección visitan ciudad por ciudad y se dignan recibir grandes elogios; al mismo tiempo, pues, procuran que el entusiasmo por ellos no se apague. En Inglaterra el Gobierno ha asumido un préstamo de 700 millones. En otros asuntos se constata el mismo trabajo cuidadoso del Gobierno. Se puede comprobar de qué manera respeta estrictamente los principios de libertad en el orden con que juzga rigurosamente a los que quieran violar el derecho domiciliario; ha sido declarada la amnistía de todos las faltas de la prensa; en las Cortes Constituyentes las colonias tendrán sus representantes; los niños nacidos de una esclava se convierten en personas libres. Los representantes del Reino en Estambul, París, Londres, Viena y Berlín serán retirados y sustituidos por otras personas.

Los pretendientes al trono de España serán, según parece, el rey de Portugal y el duque de Montpensier.

\section{4 de octubre}

Iz Madrida se piše: - 19. t.m. je bil ljudski zbor. Razgovor je bil prav živahen. Sprejeli so se ti-le nasveti: Federativna republika je edini demokratični način vladanja; vladi naj se nasvetuje, da smejo vsi Španjci, ki so 20 let stari, uživati vse politične pravice; izdajajo naj se brošure, ki bodo poučevale ljudstvo o raznih načinih vladanja; naj se ustanove politične šole za ljudstvo. -

Pravosodni minister je vkazal, da imajo nehati vsi samostani, meniški in nunski redi, kar so jih ustanovili od l. 1837 sem; njih premoženja pripadejo državi. Kar jih je bilo že pred letom 1837, bodo se zmanjšali za polovico. Vojni minister razglaša, da se imajo vseučilišča, zavodi in srednje šole l. novembra odpreti. Drugi dekret dopušča popolno svobodo uku v vseh predmetih in dovoljuje vsakemu Španjcu napraviti učilišča. Kraljica Izabela se poda $v$ Anglijo. Portugalskega kralja oče je razen mnogih druzih pripravljen ponujati se za španski prestol in je neki že francoski cesar poprašal, ali bi ga Španjci tudi hoteli. Na to odgovarja "Nacion", da bi vsako vtikanje francoskega kralja v španjske zadeve razžalilo ljudsko samostalnost; tako vtikanje bi imelo ravno nasproten vspeh, celo ko bi veljalo ponudnikom (kandidatom), ki bi bili sicer deželi všeč.

Desde Madrid se comunica: El día 19 del corriente tuvo lugar una asamblea popular. La discusión fue muy intensa. Se acordaron los siguientes consejos: el sistema de una república federal es el único democrático para gobernar; se aconseja al Gobierno establecer que todos los españoles mayores de veinte años pueden gozar de todos los derechos políticos; publicar opúsculos con los que el pueblo pueda enterarse de las diferentes maneras de gobernar el Estado; instituir escuelas políticas para el pueblo.

El ministro de Justicia ha decretado el cierre de los monasterios, de todas las órdenes monásticas, de frailes y monjas instituidos después de 1837 y que sus bienes pasen a poder del Estado, mientras que los que funcionaban ya antes de 1837 sean reducidos a la mitad. El ministro de Guerra proclama que las universidades, instituciones y escuelas de grado medio empezarán su actividad pedagógica el primero de noviembre. Otro decreto declara la libertad absoluta de la enseñanza y anima a cada español a fundar centros de enseñanza. 
La reina Isabel se marcha a Inglaterra. El padre del rey de Portugal está dispuesto, entre otros muchos, a ofrecerse para el trono español y el emperador francés ya habría preguntado a su favor si los españoles estarían dispuestos a aceptarlo. A esta iniciativa responde "Nación" que cada intromisión del monarca francés en los asuntos estrictamente españoles ofendería el sentido de independencia del pueblo; tal injerencia surtiría el efecto contrario, incluso para un candidato que fuese del agrado del pueblo.

\section{7 de octubre}

Španjska se mirno urejuje.

Kar so imeli posamezni voditelji nasprotnega in navskrižnega se je moralo opustiti, stari boji pozabiti, in osebne nevolje premagati. Glavni stranki, zmerno liberalna in demokratična ste složni, desiravno za zdaj prva nadvladuje. Izraz te sloge in pogodbe med njima je manifest, kterga je poslala začasna vlada do španjskih zastopnikov pri tujih vladah. Ta spis obširno popisuje uzroke, ki so izbudili upor. $O$ načinu prihodnjega vladanja se spis ne izreka odločno, vendar je videti iz njega, da se začasna vlada nagiblje $k$ monarhičnemu principu, nadejaje se bolje prihodnosti od ustavne države.

Torej smemo že iz zadnjega manifesta sklepati, da bo brž ko ne postala Španjska liberalna država, da bo pa svojo svobodo le na pol vživala, ker bo oklenila svojo osodo na monarha, če tudi ustavnega, namesto de bi v svobodni republiki vživala sad svojega srečnega upora. Ljudstva se še prerada prepuščajo tujemu vodstvu in lastni utragljivosti!

Francija si prizadeva, da bi se šspanjskega prestola izključile vse vladarske hiše evropskih velevlasti.

España está estabilizándose de forma pacífica. Las desavenencias que los diferentes jefes enfrentados tenían entre sí han tenido que ser dejadas a un lado; los viejos contrastes, abandonados; los rencores personales, olvidados.

Los dos principales partidos, el moderadamente liberal y el democrático, están en armonía, aunque actualmente predomina el primero. La expresión de dicha armonía y colaboración entre ambos es también el manifiesto enviado por el Gobierno Provisional a los representantes españoles en los gobiernos extranjeros. El escrito explica ampliamente las razones que han condicionado la revuelta. No se pronuncia de manera decidida sobre el sistema futuro de gobierno, de todos modos puede concluirse de su lectura que el Gobierno Provisional se inclina por el principio monárquico, esperando mejores tiempos de un estado constitucional.

Por eso podemos deducir de este manifiesto que España llegará a ser un estado liberal, pero que podrá gozar de su libertad sólo a medias: legará su suerte a un monarca, por muy constitucional que sea, en vez de gozar de los frutos de su feliz insurrección en una república libre. ¡De buen grado los pueblos se someten a una gerencia de fuera y a la propia reacción a los cambios!

Francia hace esfuerzos para excluir de la competición al trono español a todas las casas reales de las grandes potencias europeas. 
Kar je dognal španjski upor, začele so zunajne vlade kolikor toliko priznavati. $V$ saboto je sprejemal minister zunanjih zadev zastopnike anglijskega, francoskega in portugalskega, kasneje so bili zastopniki pri ministerskem predsedniku, maršalu Serrano. Celo papežev odposlanec se je priporočil prjaznosti začasne vlade. Brž ko ne se bodo po tem izgledu ravnale tudi druge vlade in ne bo dolgo, da bodo vse države, ki kaj pomenijo priznale razmere, ktere je stvaril upor. Kako se bo v prihodnje vladalo, o tem še ni gotovega. Diplomati in časniki skoraj vsak dan iznajdejo novega ponudnika za prestol, a ga zopet opuste! Tudi ni gotovo, ali sploh kteri od sedanjih in prihodnjih ponudnikov pride na prestol; glasovi, ki obetajo, da postane Španija republika na federativni podlagi, ne obmolknejo. Začasna vlada je med tem oklicala popolno svobodo tiska in ga postavila pod splošne postave, ob enem je censuro odpravila in razglasila popolno versko svobodo. Najnovejši manifest oklicuje pravico do zborov in društev, in daje posameznim okrajem večo samoupravo in še enkrat povdarja, da bo vprašanje o načinu vladanja odločeval ustavodejni zbor. Iz tega je razvideti, da bi se tudi Serrano in Prim, ki sta zdaj še uneta za monarhično vlado, podvrgla zboru, ko bi se izrekel za republiko. Sloga med strankami je neskaljena. Po najnovejših vestih je v Rimu poprašal papežev poslanec $v$ Madridu, kako se mu je obnašati glede novih razmer.

Iz Florence 4 se brzojavlja: Italijanski zastopnik v Madridu je začasni vladi takoj drugi dan, ko mu je naznanila, da se je ustanovila, izrekel, da Italija nikdar ni hotela stopiti iz dotike med obema državama.

Los gobiernos extranjeros han empezado a reconocer en mayor o menor medida lo que ha conseguido la insurrección española. Este sábado, el ministro de Asuntos Exteriores recibió, separadamente, a los embajadores de Inglaterra, de Francia, de Portugal. Acto seguido, los embajadores fueron recibidos también por el presidente del Consejo, el mariscal Serrano. Incluso el embajador de la Santa Sede suplicó benevolencia al Gobierno Provisional. Es de suponer que tal paso sea seguido también por otros gobiernos y que no haya que esperar mucho para que todos los Estados de cierta relevancia reconozcan la situación creada por el amotinamiento. Todavía no se ha dado a conocer qué forma de gobernar vaya a prevalecer en el futuro. Cada día, o casi, los diplomáticos y los periódicos descubren un nuevo pretendiente al trono para cambiar en seguida de nombre. Además, no es seguro que alguno de los pretendientes actualmente o en el futuro en juego suba al trono; continúan todavía vivas las voces que prometen una España republicana con base federal. El Gobierno Provisional, entonces, ha proclamado libertad de prensa completa y la ha colocado bajo leyes normales, ha suprimido la censura y proclamado libertad absoluta en materia de religión. El manifiesto más reciente proclama el derecho a organizar reuniones públicas y a establecer sociedades; atribuye una mayor autonomía a cada distrito y reitera que la cuestión de la forma de gobierno será resuelta por las Cortes Constituyentes. De ello se infiere que también Serrano y Prim, actualmente partidarios de un gobierno monárquico, respetarán la decisión de las Cortes, en caso de que éstas finalmente se decantasen por la república. El acuerdo entre los partidos no está enturbiado. Según las últimas noticias, el embajador de la Santa Sede en Madrid ha pedido instrucciones a Roma de cómo comportarse en la nueva situación. 
Telegrama de Florencia $a^{4}$ El representante de Italia en Madrid, al día siguiente de haberle sido comunicado por parte del Gobierno Provisional su establecimiento, hizo saber al Gobierno que Italia nunca quiso interrumpir las relaciones entre los dos Estados.

\section{1 de octubre}

Španjsko ljudstvo svojih z uporom pridobljenih pravic menda vendar ne bo tako lahkomišljeno iz rok dalo. V glavnem mestu se je zbralo mnogo ljudstva na prostoru, kjer so se obsojenci usmrtovali in je sežgalo tam stoječi šafot (oder, kjer so se obglavljenci ob glavo devali). Časniki tirjajo, naj se kaznuje grof Cheste, ker je boje zlobno govoril o ljudstvu in armadi. Revolucijonarna vlada za Sevillo ki ni še najhuja je oklicala, preden se je razšla, da monarhična vlada ne velja. Če se še pomisli, da je tudi začasna vlada konečno določitev prepustila ljudski sodbi, mora se pritrditi, da ne bo ljudstvo na Španjskem dopuščalo, da bi mu drugi nepoklicani ljudje delali njegovo osodo.

Es de esperar que el pueblo español no deje caer irreflexivamente sus derechos adquiridos durante la revolución. En la capital se han reunido muchas personas en el lugar donde ajusticiaban a los condenados; han quemado el échafaud (el patíbulo destinado a las ejecuciones). Los periódicos exigen que se castigue al conde Cheste, que habría hablado malintencionadamente sobre el pueblo y sobre el ejército. El gobierno revolucionario de Sevilla, que, a fin de cuentas, no es de los peores ha declarado no vigente al gobierno monárquico antes de dejar el mismo el desempeño de su cargo. Considerando que el mismo Gobierno Provisional ha dejado la solución final al juicio popular, tenemos que afirmar que el pueblo español no permitirá que las personas no autorizadas ni requeridas influyan en su suerte.

\section{3 de noviembre}

Španjska vlada bo ustavodajnemu zboru nasvetovala, naj bi se ondašnja armada znižala na 25.000 vojakov. Svobodni deželi ni treba bajonetov in onih, ki jih "mirno" nosijo!

El Gobierno español aconsejará a las Cortes Constituyentes reducir el ejército a 25.000 soldados. ¿Las bayonetas no sirven en un país libre, ni tampoco quienes las portan "pacíficamente"!

\section{5 de noviembre}

Evropski diplomati si še zmerom glavo belijo, da bi našli otroka ali kakega druzega človeka moškega spola, s kterim bi osrečili oproščeno Španijo. Zdaj se največ imenuje vojvoda Montpensier, in je videti, da ima mož res nekoliko svoje stranke v deželi. Franciji bi bil ta kralj trn v peti in Napoleon je že nekaj zažugal začasni vladi, da bi svoje osebe ne puščal zastopati na Montpensierovem dvoru. $V$ deželi sami pa se jih zmeraj več oglaša, ki nočejo o "osrečevalcu na prestolu" ničesar vedeti. Tako so demokrati v mest-

\footnotetext{
4 "De Florencia": entre 1865, cuando el Gobierno italiano, las Cortes y la familia real se trasladaron desde Turín, y el 1870, cuando Roma dejo de ser la capital del Estado Pontificio, la capital de Italia fue Florencia.
} 
nem zboru Madridskem nasvetovali, naj se začasni vladi izreče nezadovoljnost, ker se je drznila, predno je ljudstvo govorilo, izrekati svojo lastno misel o prihodnjem načinu vladanja in s tem hotelo občno mnenje po svoje zasukati. Največ pa se zdaj poroča o posojilih s ktermi hoče začasna vlada med drugim skrbeti ljudstvu za delo in ga tudi sicer podpirati.

Po "Corr. Hav." se republikanski časniki in rep. shajališča tako množé, da bo republikanska stranka v ustavodajnem zboru če že ne večino, imela vsaj veliko manjšino. $O$ volilni postavi in volilnih okrajih si vlada še ni prav nič jasna, volitev torej pred novim letom ne bo.

Los diplomáticos europeos están rompiéndose la cabeza para hallar a un niño o a otro hombre de sexo masculino con quien hacer feliz a la España emancipada. El que se nombra con más frecuencia es el duque de Montpensier y se constata, en efecto, que el hombre cuenta con partidarios en el país. Francia no podría ver a un rey tal ni en pintura y Napoleón ya ha amenazado al Gobierno Provisional de que su persona no contaría con representante en la corte de Montpensier. Pero en el país mismo se levantan cada día más voces que no quieren saber nada de un "bienhechor al trono". Así, los demócratas de la asamblea madrileña han acordado expresar al Gobierno Provisional su descontento por haberse éste atrevido a pronunciarse sobre el futuro régimen de gobierno antes de que el pueblo hablase, queriendo con esto influir sobre la opinión pública. Los otros informes atañen a préstamos: el Gobierno Provisional tiene intención de aliviar la vida al pueblo, procurando sobre todo más posibilidades de empleo.

Según "Correo Hav." aumentan los periódicos y los lugares de cita republicanos en tal grado que el partido republicano en las Cortes alcanzará, si no la mayoría, por lo menos una fuerte minoría.

De la ley electoral y de los distritos electorales, el Gobierno no se pronuncia de un modo claro; en todo caso, las elecciones no tendrán lugar antes del año nuevo.

Stranke na Španjskem.

Kakor se je dozdaj Španjska v svoji celoti složna in edina kazala, razdeljena je vendar v 4 glavne stranke, ktere si bodo pri prihodnjih volitvah prizadevale, da se izvoli ustavodejni zbor v njihovem smislu. Madridski dopisnik pariškega "Tempsa" takole opisuje različne stranke:

1. Začasna vlada s svojo stranko, ki jo je izvolila. Njena glavna moč je vojska: močno se čuti še tudi za to, ker meni, da so njeni nasprotniki skoraj brez vsake moči.

2. Mnogoštevilna napredovalna stranka, ktera priznava, da bi se brez pomoči prve stranke dinastija ne bila spremenila - in ta sprememba je vendar prvi pogoj prihodnjih državnih poprav - vendar pa, kakor tudi 1. stranka noče predaleč na revolucijonarni poti. Tudi ta stranka priznava dejansko nadvlado vojaštva, ktero bo morebiti tudi še v svoje namene rabila. Te dve stranki sta precej trdno in resno zvezani; niste si namrec navskrižnih misli, kar se tiče načina vladanja, ponudnika za prestol in glavnih načel; vendar hočejo napredovalci sklicevaje se na potrebo federacije pustiti posameznim provincijam precej obširno samostojnost, ne le upravno ampak tudi narodno-gospodarsko. To stranko stvarja manjše in veče meščanstvo obrtnijskih in kupčijskih pokrajin. 
3. Demokratična stranka med seboj needina, in vedno pripravljena stati v opoziciji. Vendar pa se posamezni oddelki te stranke med seboj približujejo in je upati, da se konečno vredijo. Njen uzor je popolna ljudska samostalnost. Ta stranka ima mnogo izvrstnih glav, manjka jej pa prave izdatne, stanovitne delavnosti. Koliko ta stranka premore, ne da se povedati: ona tega sama ne vé. Vendar je verjetno, da bi s to stranko, ako bi bila o pravem času dovolj složna in gibčna, šlo vse prebivalstvo južnih primorskih mest.

4. Klerikalna stranka, ktera pa popisovalcu, kakor sam priznava, v njenem namenu in pomenu ni prav nič jasna. Ako se sme verjeti neki govorici, popolnoma je ta stranka prepričana, da se bodo izvršile prihodnje volitve $v$ njenem smislu; $v$ nekaterih pokrajinah ima prav mnogo veljave. Vendar bi se niže duhovstvo ne obotavljalo mnogo in priznalo sedanje razmere, ko bi jo viši po svoje ne vodili.

Vse te stranke imajo še svoje posebne oddelke, ktere pa naštevati bi bilo predolgo in pretežavno.

Publicado en una columna especial, siempre el día 5 de noviembre:

Los partidos políticos españoles.

A pesar de que España demuestre estar concorde y unida, resulta todavía dividida en cuatro partidos políticos principales, los cuales, con ocasión de las próximas elecciones harán todo lo posible por obtener el mejor resultado y ganar el mayor número de escaños posibles en las Cortes Constituyentes. El corresponsal madrileño del periódico de París "Temps" presenta los diferentes partidos políticos de este modo:

1. El Gobierno Provisional con su partido que lo ha elegido. Su fuerza principal es el ejército; se considera fuerte también porque considera débiles, casi sin fuerza, a todos sus adversarios.

2. El amplio partido progresista, que reconoce que sin ayuda del primer partido el cambio de dinastía no sería posible - y tal cambio es la primera condición para las futuras correcciones del Estado - aunque, como también el primer partido, no quiere adelantarse demasiado por el camino revolucionario. Este partido también reconoce la efectiva supremacía del ejército, que en el futuro le podría resultar útil. Los dos partidos están ligados entre ellos con lazos bastante serios y válidos; están de acuerdo sobre el régimen de gobierno, sobre el pretendiente al trono, sobre las principales ideas. Los progresistas, de todas formas, remitiéndose a la necesidad de una federación, querrían dejar a cada una de las provincias una amplia autonomía, no solamente administrativa sino también nacional y económica. Constituyen este partido la pequeña y mediana burguesía de las comarcas de la artesanía y el comercio.

3. El partido demócrata, no unitario y siempre listo para mostrar disensiones. Aun así, cada una de sus partes están acercándose y hay que esperar que finalmente se pongan de acuerdo. El ideal del partido es la total independencia del pueblo. Este partido cuenta con muchos dirigentes de primer orden pero le falta todavía una unidad de acción constante y verdadera. No es posible decir cuántos seguidores tiene; ni el propio partido lo sabe. Pero es de esperar que en las elecciones pueda obtener votos de las ciudades costeras del sur, a condición de que en el momento justo se muestre bastante cohesionado y hábil. 
4. El partido clerical, que para el periodista, como él mismo reconoce, no tiene claros cuáles son sus fines e intenciones. Si se puede dar crédito a ciertos rumores, el partido está convencido de poder ganar las próximas elecciones; en algunas comarcas tiene verdaderamente mucho vigor. Con todo, el bajo clero no vacilaría mucho a la hora de reconocer la situación actual a condición de que la alta jerarquía no le impusiese su visión.

5. Todos los partidos tienen además sus divisiones; sería demasiado largo y difícil enumerarlas.

10 de noviembre

Iz Madrida se brzojavlja: Pravosodni minister je ustavil onih 51.090 .000 realov, kar so diecezijska semenišč $v$ podporo prejemala.

Telegrama desde Madrid: El ministro de Justicia ha detenido la entrega de los 51.090 .000 reales que hasta ahora recibían como sostén los seminarios diocesanos.

12 de noviembre

Špansko ministrstvo pridno imenuje više uradnike.

General Prim, generalni kapitan vse španske vojske, je razposlal okrožnico do posameznih vojnih oddelkov, $v$ kteri pa opominja da armada nima nobene druge moralične ali materijalne moči, nego ono, za ktero je bila ustanovljena.

Vojni zapoveljniki posameznih španjskih pokrajin so tirjali, naj se jim število vojaštva pomnoži. Prim je odgovoril, da je to nemogoče, ker bi više vojaštvo presegalo deželne moči. Vlada računa, da jo bo dežela podpirala. Da pa se vendar stori, kar vlada storiti more, zbrala bo mnogo vojaštva v Novi Kastilji, kjer se stakajo vse železnice in telegrafi, od koder se bodo torej vojne čete lahko razposlale, kjer jih bo ravno treba.

El ministerio español está nombrando, con solicitud, altos funcionarios públicos.

El general Prim, capitán general de todo el ejército español, ha repartido una circular a cada uno de los destacamentos militares en la que advierte que el ejército no tiene otro poder, ni moral ni material, sino aquel para el que fue creado.

Los comandantes militares de cada una de las provincias españolas han exigido el aumento del efectivo. Prim ha contestado que era cosa imposible ya que tal aumento excedería las posibilidades del país. El Gobierno cuenta con el apoyo del país. Pero, para cumplir con su deber, el Gobierno concentrará bastantes tropas en Castilla la Nueva, donde se reúne toda la red de ferrocarril y también de telégrafos y desde donde las tropas podrían ser enviadas a donde hiciese falta en caso de necesidad. 
29 de octubre

\section{RAZNE STVARI}

Španjska ima v Evropi z Balearskimi in Kanarskimi otoki vred 9200 štirjaških milj in 15.673.536 prebivalcev. Po prostoru je Španjska 5. država v Evropi, po številu prebivalcev osma. Po kolonijah ima še 8700 štirjaških milj zemlje in 6 1/3 milj. prebivalcev. Evropska Španjska je razdelena $v 49$ provincij. 4 mesta imajo nad 100.000 prebivalcev, 5 med 50 - 100.000, vsa druga mesta imajo manj kot 50.000 ljudi.

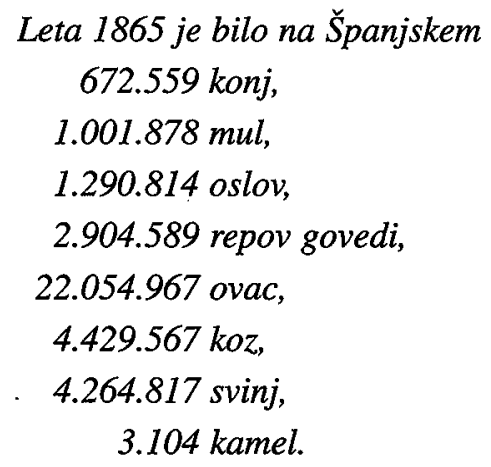

Po zapiskih leta 1860 se je obrtnije vdeleževalo

12.471 fabrikantov,

333.280 obrtnikov,

665.651 rokodelcev,

154.200 fabr. delavcev,

razen tega pa je

23.000 rudarjev,

5.066 železniških služabnikov.

Železnica je imela leta 1867611 milj.

Španjska ima 117 luk in je štela 1864 leta 4.613 kupčijskih ladij.

Ljudskih šol je imela 23.353, ktere je 1860 obiskovalo 1.101 .529 šolarjev. Pisati in brati zna le peti del prebivalstva. 


\section{DATOS VARIOS}

España tiene en Europa, junto con Baleares y Canarias, 9200 leguas cuadradas y 15.673.536 habitantes. Por su extensión es España el quinto Estado europeo; el octavo, por el número de habitantes. En sus colonias cuenta, además, con 8700 leguas cuadradas de tierra y $61 / 3$ millones de habitantes. La España europea está dividida en 49 provincias, cuatro ciudades superan los 100.000 habitantes, 5 están entre los 50.000 y 100.000 habitantes, todas las demás tienen menos de 50.000 .

En el año 1865 había en España:

672.559 caballos

1.000 .878 mulas

1.290 .814 burros

2.904.589 cabezas de bovino

22.054 .967 ovejas

4.429.567 cabras

4.264.817 cerdos

3.104 camellos.

Según las estadísticas de 1860 había en la artesanía empleados:

12.471 obreros

333.280 artesanos

665.651 obreros manuales

154.200 obreros de trabajos rudos.

$\mathrm{Y}$ además:

23.000 mineros

5.066 trabajadores de ferrocarril.

En 1867 España poseía 611 leguas de líneas de ferrocarril.

España posee 117 puertos. En 1864 poseía 4.613 barcos mercantes.

Había 23.353 escuelas primarias, a las que acudían, en 1860, 1.101 .529 alumnos.

En el país, sólo un quinto de la población es capaz de leer y escribir.

$$
*
$$

Así, en Slovenski Narod de 1868.

Para concluir: España, ¿para los eslovenos de aquella época španska vas? Sí. No. No exactamente. 
Prvo leto izhajanja Slovenskega naroda, tedaj še v Mariboru, je za Španijo leto revolucije in upora proti vladavini Izabele II, iz dinastije francoskih Burbonov. Mladi slovenski časnik prinaša veliko obvestil o vrenju v kraljevini na Iberskem polotoku, povzema iz francoskega časopisja komentar o španskih političnih strankah in objavlja tudi statistične podatke o Španiji; ta dežela torej bravcu tega liberalnega časopisa le ni bila tako neznana, kot bi utegnili sklepati iz znanega slovenskega reka. O nobeni drugi državi zunaj avstro-ogrske monarhije se $\mathrm{v}$ tem letniku časopisa ne govori toliko kot o Španiji: francosko-pruska vojna se je leta 1868 šele najavljala. Naš prispevek prepisuje poročila o Španiji; je pa iz njih vidna liberalna, predvsem protiklerikalna usmeritev časopisa, pa tudi prikrita zaverovanost $\mathrm{v}$ republikansko ureditev države: najbrž si lahko zamišljamo, da je imel časnikar pred očmi težnje $v$ svoji domovini,ali vsaj težnje liberalne levice, česar pa na glas seveda ni mogel povedati. 